\title{
Structures of Strong Sectors of the Russian Federation Subjects and Assessment of Their Economic Complexity
}

\author{
Afanasiev M.* Kudrov A. \\ Central Economics and Mathematics Institute of the Russian Academy of Sciences, Russia, Moscow \\ *Corresponding author. Email: miafan@cemi.rssi.ru
}

\begin{abstract}
The problem of grouping regions by the structure of strong sectors, identifying the characteristics of the formed groups and assessing their economic complexity is considered. A strong sector is considered as an element of the structure of the region's economy, the share of production volume of which is higher than for the Russian Federation as a whole. A metric was used to determine the proximity of any two regions according to the structure of strong sectors. Using this metric, minimal spanning trees were constructed to identify groups of regions with a close structure of strong sectors. The structures revealed in this way can be considered as basic when choosing the directions of development of the subjects of the Russian Federation. The results of grouping the regions according to the structure of strong sectors do not contradict the results of clustering the regions previously obtained by the authors according to the sectoral structure of the GRP and make it possible to clarify the structure of the economy of the regions previously included in the "uniformly developed" cluster. For each group, codes and names of sectors that are its distinctive feature, as well as codes of sectors strong for all regions of the group are given. This information quite fully characterizes the structure of the economic complexity of the regions and can be used to solve project management tasks.
\end{abstract}

Keywords: economy of a region, economic complexity, strong sector, minimal spanning tree

\section{INTRODUCTION}

Modern ideas about economic complexity are associated with the diversification of production. Countries exporting more "sophisticated" goods usually have a higher level of per capita material welfare than countries exporting simple goods. Moreover, a structural transformation of the economy and a transition from simpler forms of production to more complex ones is possible. Such a transition is accompanied by an increase in the level of socio-economic development. More recently, a procedure has been developed that allows measuring the economic complexity of both sectors and the structure of the economy as a whole (Hartmann, 2017; Hausmann, Hwang, Rodrik, 2006; Hausmann, Rodrik, 2003; Hidalgo, Hausmann, 2009). The proposed measure of economic complexity has earned widespread attention because it is highly significant in models for forecasting economic growth. In addition, this measure is well correlated with indicators of material well-being and other characteristics of socio-economic development. However, the used methodology for calculating economic complexity does not take into account the volume of domestic consumption of manufactured products.

Further, in contrast to the traditional approach, according to which the concept of the revealed comparative advantages (Balassa, 1965) is applied to manufactured products, the study of sectors of the region's economy is emphasised. The problem of grouping regions by the structure of strong sectors, identifying the characteristics of the formed groups of regions and assessing their economic complexity is considered. The obtained results can be used to solve the problems of project management.

\section{RESEARCH METHODOLOGY}

To describe the structure of strong sectors of the region's economy, we use the author's generalization of the approach to assessing economic complexity described in (Hausmann et al., 2011; Balassa, 1965; Lyubimov, Gvozdeva, Kazakova, 2017), based on the use of data on tax revenues by sector of the economy. These data take into account the output of each sector of the economy for export and for domestic consumption.

Prerequisite 1. Data on tax revenues reflect the proportions of production volumes of sectors of the economy in value terms.

The indicator of the identified comparative advantages is determined by the formula:

$$
R C A_{c p}=\left(y_{c p} / \sum_{p} y_{c p}\right) /\left(\sum_{c} y_{c p} / \sum_{c p} y_{c p}\right),
$$

where $y_{c p}$ is the volume of tax revenues from sector $p$ of the region's economy c. Accordingly, $R C A_{c p}$ is the ratio of the share of tax revenues from sector $p$ in the total amount of tax revenues from all sectors of the region's economy $c$ to the share of tax revenues from sector $p$ for all regions in the number of tax revenues from all sectors of all regions 
economy. In accordance with studies in which the $R C A_{c p}$ indicator is used to assess the revealed comparative advantages in economies (Hausmann, Klinger, 2006), a lower restriction is imposed on it. If the $R C A_{c p}$ value exceeds unity, then, taking into account premise 1 , we can assume that the economy of the region $c$ has revealed comparative advantages in the output of sector $p$. Otherwise, it is considered that the identified comparative advantages do not exist. Using $R C A$, a matrix $M$ is determined that contains data on sectors of the economy that are developed in different regions at the level of the revealed comparative advantages determined using expression (1). Rows of this matrix correspond to regions, columns to sectors of the economy. The element $x_{c p}$ matrix $M$ is 0 if the region has no identified comparative advantages in the production of sector $p$, determined using expressions (1), and 1 otherwise. That is, the condition

$$
x_{c p}=\left\{\begin{array}{l}
1, \text { if } R C A_{c p}>1 \\
0, \text { if } R C A_{c p} \leq 1
\end{array} .\right.
$$

is met.

Using the matrix $M$, one can obtain characteristics of the region's economy diversification level, identifying strong sectors the products of which the region produces at the level of revealed comparative advantages, and also indices are calculated allowing a comparative analysis of the economic complexity of different regions.

To form groups of regions close in structure to strong sectors, an approach based on graph theory was used. Based on the matrix $M$, which describes the structure of the constituent entities strong sectors of the Russian Federation, we construct a hierarchy of relationships between the structures of strong sectors in the form of the so-called "minimal spanning tree" and study its topological properties. There are the works in which the "minimum spanning trees" were used for correlation networks:

- stock prices of companies traded on the US markets (Onnela et al., 2002; Onnela, 2006), the UK (Coelho et al., 2007) and Japan (Jung et al., 2008). One of the important results obtained in these works is the detection of the shares of companies grouping from one sector on the "branch of the minimum spanning tree";

- data of magnetoencephalography of various parts of the human brain. Identification and study of the functional modules of the brain using magnetoencephalographic metrics provide for more accurately determining the target areas of the brain if surgery is necessary. As a result of the use of minimal spanning trees, functional modules of the brain were obtained, consisting of sections performing common functions and located along the "branches" of the tree (Lee et al., 2006; Stam et al., 2014);

- indicators in the construction of indicators of socioeconomic development (Aivazian, Afanasiev, Kudrov, 2019).

We denote the undirected graph of relationships for the structures of the economic complexity of the regions, each of which is described by a row of the matrix $M$, through $G$ $=(V, E)$ where $V$ is a set of nodes, each of which corresponds to a region from the set of $\mathrm{m}$ regions under consideration; $E$ is the set of edges. Using the edge $E$, nodes $V$ are connected. Each edge is characterized by the strength of the relationship or the distance between the respective nodes.

More formally, at a fixed point in time for each region $c \in\{1, \ldots, \boldsymbol{m}\}$, where $\mathrm{m}$ is the number of regions under consideration, there is a row vector of the $X_{c}=\left(x_{c, 1}, \ldots, x_{c, n}\right)$ matrix $M$ that describes the structure of the strong sectors of region $c$ (here $n$ is the number of economic sectors). We define the distance between the vectors $\mathrm{Xi}$ and $\mathrm{Xj}, i, j \in\{1, \ldots, m\}$ as

$$
d\left(X_{i}, X_{j}\right)=\sqrt{1-\left(\frac{2\left(X_{i}, X_{j}\right)}{\left|X_{i}\right|+\left|X_{j}\right|}\right)^{2}} .
$$

Value $\frac{\left(X_{i}, X_{j}\right)}{\left|X_{i}\right|+\left|X_{j}\right|}$ - the share of total strong sectors in the total number of strong sectors of two regions. If the structures of the strong sectors of the two regions coincide, then $X_{i}=X_{j}$ and $d\left(X_{i}, X_{j}\right)=0$. In this case, the regions do not differ in the structure of strong sectors and will be assigned to the same group with the general structure of economic complexity. If the regions do not have common strong sectors, then $d\left(X_{i}, X_{j}\right)=1$ the "distance" between the structures of strong sectors is the biggest, the regions fall into different groups.

Definition (covering tree). A subgraph $G^{\prime}=\left(V, E^{\prime}\right)$ of a graph $G$ is called a spanning tree if in it all nodes of $V$ are connected through $|V|-1$ edge.

It can be shown that a graph $G$ will be connected if and only if there is a covering tree for it. Suppose graph $G$ is connected. Then there exists at least one covering tree of the graph $G$. Among all the covering trees of the graph $G$, we will be interested in a certain sense of the minimum: Definition (minimum spanning tree). A spanning tree $\tilde{G}^{y}$ for a graph $G$ is called a minimal spanning tree, if

$$
\tilde{G}^{y}=\operatorname{argmin}_{G^{\prime} \in H} \sum_{\left(X_{i}, X_{j}\right) \in E^{\prime}} d\left(X_{i j}, X_{j}\right)
$$

where $H$ is the set of all covering trees of graph $G$.

The use of minimal spanning trees makes it possible to identify groups of close nodes of the graph $G$, extracting from the matrix $M$ the strongest bonds in the structure of strong sectors. As a result, close nodes of the graph $G$ line up in the form of a "branch" of a minimal spanning tree. Although the transition to a minimum spanning tree is accompanied by the loss of quite a few links between 
indicators, it allows us to identify the "branches" of indicators characterized by a single specificity.

There are a number of algorithms for constructing a minimal spanning tree of graph $G$. In this study, the Kruskal algorithm (Kruskal, 1956) was used to construct a minimum spanning tree.

The concept of economic complexity of a region is considered as a characteristic reflecting the level of technological development of a region, which, in turn, is determined by strong sectors in the structure of its economy. Similarly, the economic complexity of a sector depends on the level of technological development of those regions in which this sector is present in the structure as strong. Let us give a more formal definition of economic complexity corresponding to the procedure for its calculation presented in (Hausmann, Hidalgo et al., 2011):

a) the economic complexity of a region $\left(E C I_{c}\right)$ or sector $\left(E C I_{c}\right)$ is a latent characteristic;

b) The economic complexity of a region is proportional to the average level of economic complexity of strong sectors in the structure of its economy. Namely:

$$
E C I_{c}=a_{1} \sum_{p} w_{c, p} E C I_{p},
$$

Where $w_{c, p}=\frac{M_{C, p}}{k_{c, 0}}, \quad k_{c, 0}=\sum_{p} x_{c, p}, \quad a_{2}-$ positive constant.

c) the economic complexity of the sector is proportional to the average level of economic complexity of the regions in the structure of the economies of which this sector is strong:

$$
E C I_{p}=a_{2} \sum_{c} w_{p, c}^{*} E C I_{p}
$$

Where $w_{p, c}^{*}=\frac{M_{C_{p} p}}{k_{d_{l}, 0}}, \quad k_{d_{2} 0}=\sum_{c} x_{c, p}, \quad a_{2}-$ positive constant.

We introduce some additional notation:

$\mathbf{c}=\left(E C I_{c_{1}}, E C I_{c_{2}}, \ldots\right)-$ a vector of values of economic complexity for the regions;

$\mathbf{p}=\left(E C I_{p_{1}}, E C I_{p_{2}}, \ldots\right)$ - vector of economic complexity values for sectors;

$\mathbf{W}_{1}=\left(w_{c i p}\right), \mathbf{W}_{2}=\left(w_{p, c}^{*}\right)$ - matrices of weights.

We write properties $b$ ) and c) in matrix form:

$\mathbf{c}=a_{1} \mathbf{W}_{1} \mathbf{p}, \mathbf{p}=a_{2} \mathbf{W}_{2} \mathbf{c}$. From which it follows

that:

$$
\mathbf{c}=a_{1} a_{2} \mathbf{W}_{1} \mathbf{W}_{2} \mathbf{c}_{y} \mathbf{p}=a_{1} a_{2} \mathbf{W}_{2} \mathbf{W}_{1} \mathbf{p}
$$

Thus, the economic complexity of the region is defined as the eigenvector of the matrix $\boldsymbol{W}_{\boldsymbol{1}} \boldsymbol{W}_{2}$, and the economic complexity of the sector is the eigenvector of the matrix $\boldsymbol{W}_{2} \boldsymbol{W}_{\boldsymbol{1}}$. In (Hausmann, Hidalgo et al., 2011), it is proposed to use the standardized second main component of the matrices $\boldsymbol{W}_{1} \quad \boldsymbol{W}_{2}$ and $\boldsymbol{W}_{2} \quad \boldsymbol{W}_{1}$ as values of economic complexity estimates. It should be noted that the coordinates of the first principal component for these matrices consist of the same values, since they are stochastic (Hidalgo, Hausmann, 2009), (Kemp-Benedict, 2014). We also recall that if $\mathrm{x}$ is an eigenvector for the matrix A corresponding to the eigenvalue $\lambda$, then the vector $r \mathbf{x}$, where $r$ is any nonzero real number, is also an eigenvector of the matrix A corresponding to the same eigenvalue $\lambda$.

Briefly describe the procedure for calculating economic complexity:

1. According to the matrix $M=\left(x_{c p p}\right)$, we calculate the characteristics of diversification $\left(k_{c_{2}, 0}\right)$ and uniqueness of the $\operatorname{sector}\left(k_{p, 0}\right)$ :

$$
k_{c, 0}=\Sigma_{p} x_{c, p} \text { and } k_{p, 0}=\Sigma_{c} x_{c, p}
$$

2. Let us calculate the matrix $\boldsymbol{W}_{\boldsymbol{I}} \boldsymbol{W}_{2}$, the elements of which characterize the degree of similarity of sets of strong sectors in the structure of economies of the corresponding pair of regions under consideration. The similarity metric used is a weighted sum over all common sectors, where weights provide a greater contribution to those sectors that correspond to a higher level of uniqueness $\left(k_{p, 0}\right)$. It is easy to see that the element of the matrix $\boldsymbol{W}_{1} \boldsymbol{W}_{2}$ at the intersection of the row $\boldsymbol{c}_{\text {and }}$ column $c^{*}$ is calculated according to the formula:

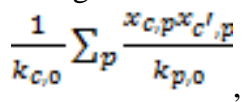

Where $c, c^{x}$ - region numbers.

Note that if $k_{p, 0}$ takes the same value for all $p$, then $\widetilde{M}_{c_{e} c^{\prime}}$ are equal to the share of common sectors of the strong sectors number in the region $c$.

Similarly, we calculate the matrix $\boldsymbol{W}_{\mathbf{2}} \boldsymbol{W}_{\boldsymbol{l}}$, in which the $\left(p, p^{J}\right)$ - element is calculated by the formula:

$$
\frac{1}{k_{p, 0}} \sum_{c} \frac{x_{C p x_{C p^{\prime}}}}{k_{C_{0} 0}}
$$

Where- $p, p^{s}$ sector numbers.

3. Finally, the region's economic complexity index is calculated as the standardized value of the second principal component of the matrix $\boldsymbol{W}_{\boldsymbol{1}} \boldsymbol{W}_{2}$. Namely:

$$
\mathbf{c}=\left(\begin{array}{c}
\frac{\mathrm{f}_{1}-\mathrm{f}}{d} \\
\frac{\mathrm{f}_{2}-\overline{\mathrm{f}}}{d} \\
\mathrm{w}
\end{array}\right)
$$

where the vector $\mathbf{f}=\left(f_{1}, \ldots\right)$ is an eigenvector corresponding to the second main component of the matrix $\boldsymbol{W}_{\boldsymbol{1}} \boldsymbol{W}_{2}, \overline{\mathrm{f}}$ is the average value of the coordinates of the vector $\mathrm{f}, d$ is the standard deviation calculated for the coordinates of the vector $f$.

Also, the economic complexity index of economic sectors is calculated as the standardized value of the second main component of the matrix $\boldsymbol{W}_{2} \boldsymbol{W}_{1}$. Namely: 


$$
\mathbf{p}=\left(\begin{array}{c}
\frac{\mathrm{E}_{1}-\overline{\mathrm{g}}}{e} \\
\frac{\mathrm{E}_{2}-\overline{\mathrm{g}}}{e} \\
\cdots
\end{array}\right)
$$

where the vector $\mathbf{g}=\left(g_{1}, \ldots\right)$ is an eigenvector corresponding to the second main component of the matrix $\boldsymbol{W}_{2} \boldsymbol{W}_{1}, \overline{\mathrm{f}}$ is the average value of the coordinates of the vector $\boldsymbol{g}, \boldsymbol{e}$ is the standard deviation calculated for the coordinates of the vector $g$.

\section{RESEARCH RESULTS}

To form the matrix $\mathrm{M}$ of the structure of the strong sector, we used data on tax revenues for 82 sectors of the constituent entities economy of the Russian Federation. The number of strong sectors in the economy of each region is indicated in column 4 of the Table 1 . Regions with the most diversified economies (with a large number of strong sectors): Tver Oblast (42), Chuvash Republic (40), Moscow Oblast (39), Novosibirsk Oblast (39), Vladimir Oblast (37), Lipetsk Oblast (36). The least diversified economies are in the following regions: Orenburg Oblast (6), Tyumen Oblast (8), Astrakhan Oblast (9), Tomsk Oblast (10), Republic of Sakha (Yakutia) (11). The minimum spanning tree for the correlation $\operatorname{graph} G=(V, E)$ constructed using the Kruskal algorithm based on the matrix $M$ characterizing the structure of strong sectors of the regions is shown in Fig. 1

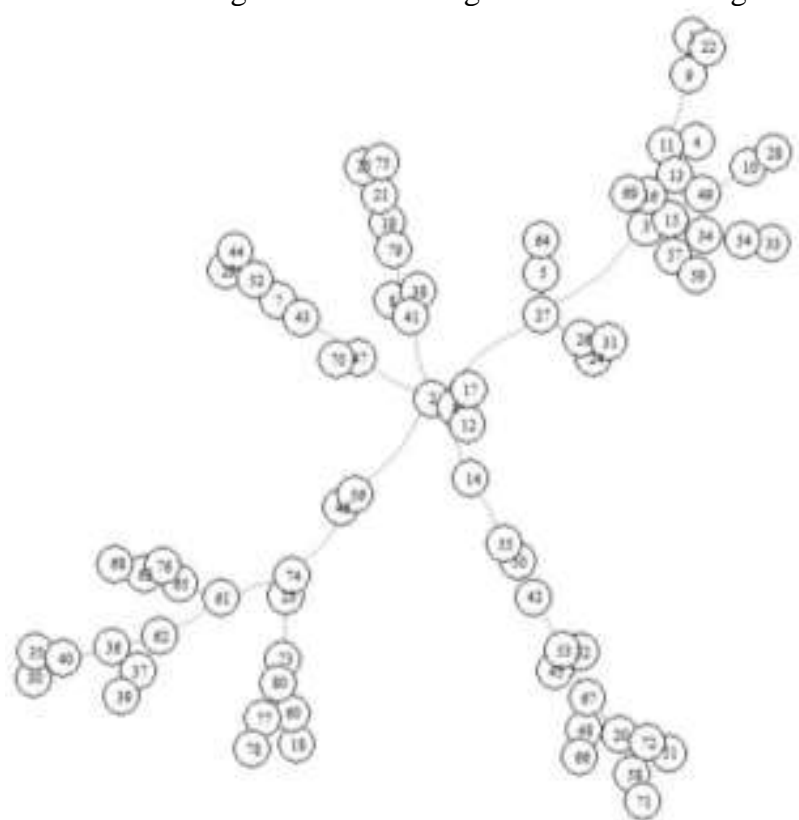

Figure 1 Minimum spanning tree for grouping regions by the structure of strong sectors

In Figure 1, each vertex of the tree characterizes the subject of the Russian Federation. The vertices are numbered in the order used in column 1 of the Table 1. The arc length is the proximity of two regions according to the structure of strong sectors in the metric (3). There are one or several groups of regions on each branch of the tree that are similar in structure of economic complexity. Based on the visualization of the minimum spanning tree and expert analysis of the matrix $\mathrm{M}$ of strong sectors, thirteen groups of regions were identified, which are presented in the Table 1. Column 6 of this Table shows the number of the group of regions that are close in metric (3) in terms of the structure of strong sectors. Identified groups have two properties: each group corresponds to the structure of a minimal spanning tree; for each group, one, two or three sectors were identified that are strong in the structure of economic complexity for all regions of only this group. Thus, each group of regions is matched by strong sectors of the economy characteristic of all regions only for this group. Sector codes and names are listed in column 7 of the Table 1. These sectors are a distinctive feature of the corresponding group of regions. Column 7 of the Table 1 also shows the codes of sectors strong for all regions of the group, which at the same time are strong sectors for all sectors of some other group. As well as codes (in italics) of sectors that are strong for all regions of the group, with the exception of one, which can also be strong sectors for regions belonging to other groups. This information quite fully characterizes the structure of the economic complexity of the regions included in each group.

The economic complexity index is presented in column 5 of matrix 1. For each group of regions, estimates of economic complexity are obtained as the average value of the indices of the regions included in the group. Moreover, for the stability of group ratings, the highest and lowest ratings were not taken into account in each group. In the Table 1, groups of regions similar in structure to strong sectors are sorted in descending order of estimates of economic complexity. It should be noted that the ordering of groups is preserved if estimates of economic complexity are calculated as the average value of the ranks of the regions included in the group.

\section{DISCUSSION}

When describing the specifics of groups of regions similar in metric (3) in terms of the structure of strong sectors, we will compare them with the regional clusters presented in (Aivazian, Afanasyev, Kudrov, 2016). Based on the author's approach, according to the data on the GRP sectoral structure, the regions were divided into five clusters: 1) "evenly developed", 2) "mining", 3) "processing", 4) "agricultural", 5) "developing". The cluster number is indicated for each region in column 3 of the Table 1. The relationship between the composition of groups of economic complexity and the composition of clusters can be traced by comparing the data on the regions belonging to them, indicated in columns 3 and 6 of Table 1. Almost all (11 out of 12) "processing" regions were included in the first 5 groups with the highest estimates of economic complexity. Almost all (9 out of 11) "mining" regions were included in the last three groups with the lowest estimates of economic complexity. Most (6 out of 
"agricultural" regions are in 2,3,4 and 5 groups of complexity.
8) of "developing" regions were included in the eighth group. Two more "developing" regions are in groups with lower estimates of economic complexity. Most (6 of 11)

Table 1 Structures of strong sectors and estimates of economic complexity

Column Name:

(1) Region No. in the ordering used by Rosstat,

(2) name of the region

(3) cluster number of the region according to the structure of GRP,

(4) the number of strong sectors in the region,

(5) economic complexity index

(6) group number of the region according to the structure of strong sectors,

(7) codes and names of complex sectors of all regions of only this group, codes of sectors of all regions of the group, codes (in italics) of sectors of all but one region of the group.

\begin{tabular}{|c|c|c|c|c|c|c|}
\hline (1) & (2) & (3) & (4) & (5) & (6) & (7) \\
\hline 1 & $\begin{array}{l}\text { Belgorod } \\
\text { region }\end{array}$ & 1 & 24 & 0.920 & \multirow[t]{3}{*}{1} & \multirow{3}{*}{$\begin{array}{l}1170 \text { metallurgical production and manufacture of finished metal products; } \\
1175 \text { production of cast iron, steel and ferroalloys; } 1135 \text { manufacture of paper } \\
\text { and paper products; } \\
\text { 1020, 1100, 1110,1165, 1250; } \\
1090.1255,1261,1420 \text {. }\end{array}$} \\
\hline 22 & $\begin{array}{l}\text { Vologda } \\
\text { region }\end{array}$ & 3 & 25 & 0.786 & & \\
\hline 9 & $\begin{array}{l}\text { Lipetsk } \\
\text { region }\end{array}$ & 3 & 36 & 0.662 & & \\
\hline 33 & $\begin{array}{l}\text { Volgograd } \\
\text { region }\end{array}$ & 1 & 17 & 0.707 & \multirow[t]{10}{*}{2} & \multirow{10}{*}{$\begin{array}{l}1160 \text { manufacture of rubber and plastic products; } 1200 \text { casting of metals; } \\
1020,1165,1261,1305 \text {; } \\
1400,1410,1420 \text {. }\end{array}$} \\
\hline 13 & $\begin{array}{l}\text { Smolensk } \\
\text { region }\end{array}$ & 1 & 31 & 0.388 & & \\
\hline 11 & Oryol region & 1 & 30 & 0.608 & & \\
\hline 54 & $\begin{array}{l}\text { Saratov } \\
\text { region }\end{array}$ & 1 & 21 & 0.329 & & \\
\hline 16 & Tula region & 3 & 34 & 0.409 & & \\
\hline 59 & $\begin{array}{l}\text { Chelyabinsk } \\
\text { region }\end{array}$ & 3 & 35 & 0.727 & & \\
\hline 57 & $\begin{array}{l}\text { Sverdlovsk } \\
\text { region }\end{array}$ & 3 & 30 & 0.674 & & \\
\hline 3 & $\begin{array}{l}\text { Vladimir } \\
\text { region }\end{array}$ & 3 & 37 & 0.771 & & \\
\hline 4 & $\begin{array}{l}\text { Voronezh } \\
\text { region }\end{array}$ & 4 & 34 & 0.652 & & \\
\hline 34 & Rostov region & 4 & 33 & 0.708 & & \\
\hline 12 & $\begin{array}{l}\text { Ryazan } \\
\text { region }\end{array}$ & 1 & 16 & 0.776 & \multirow[t]{6}{*}{3} & \multirow{6}{*}{$\begin{array}{l}1125 \text { manufacture of leather and leather products; } \\
1095,1203,1250 \text {; } \\
1100,1110,1255,1261,1400 \text {. }\end{array}$} \\
\hline 38 & $\begin{array}{l}\text { Karachay- } \\
\text { Cherkess } \\
\text { Republic }\end{array}$ & 1 & 27 & 0.414 & & \\
\hline 2 & $\begin{array}{l}\text { Bryansk } \\
\text { region }\end{array}$ & 1 & 31 & 0.542 & & \\
\hline 8 & Kursk region & 1 & 22 & 0.686 & & \\
\hline 17 & $\begin{array}{l}\text { Yaroslavl } \\
\text { region }\end{array}$ & 3 & 25 & 0.453 & & \\
\hline 6 & Kaluga region & 3 & 29 & 0.732 & & \\
\hline
\end{tabular}




\begin{tabular}{|c|c|c|c|c|c|c|}
\hline 41 & $\begin{array}{l}\text { Stavropol } \\
\text { region }\end{array}$ & 4 & 23 & 0.553 & & \\
\hline 44 & $\begin{array}{l}\text { Republic of } \\
\text { mordovia }\end{array}$ & 1 & 20 & 0.599 & \multirow[t]{7}{*}{4} & \multirow{7}{*}{$\begin{array}{l}1100 \text { production of dairy products; } \\
\text { 1020,1130; } \\
1400,1410,1420,1430,1440 \text {. }\end{array}$} \\
\hline 43 & $\begin{array}{l}\text { Republic of } \\
\text { Mari El }\end{array}$ & 1 & 31 & 0.507 & & \\
\hline 47 & $\begin{array}{l}\text { Chuvash } \\
\text { republic }\end{array}$ & 1 & 40 & 0.569 & & \\
\hline 7 & $\begin{array}{l}\text { Kostroma } \\
\text { region }\end{array}$ & 1 & 33 & 0.284 & & \\
\hline 70 & Omsk region & 3 & 17 & 0.372 & & \\
\hline 52 & Penza region & 4 & 26 & 0.646 & & \\
\hline 29 & $\begin{array}{l}\text { Republic of } \\
\text { Adygeya }\end{array}$ & 4 & 22 & 0.222 & & \\
\hline 55 & $\begin{array}{l}\text { Ulyanovsk } \\
\text { region }\end{array}$ & 1 & 25 & 0.324 & \multirow[t]{4}{*}{5} & \multirow{4}{*}{$\begin{array}{l}1205 \text { production of machinery and equipment; } \\
1220 \text {; } \\
1165 .\end{array}$} \\
\hline 42 & $\begin{array}{l}\text { Republic of } \\
\text { Bashkortostan }\end{array}$ & 3 & 17 & -0.305 & & \\
\hline 50 & $\begin{array}{l}\text { Nizhny } \\
\text { Novgorod } \\
\text { region }\end{array}$ & 3 & 24 & 0.739 & & \\
\hline 14 & $\begin{array}{l}\text { Tambov } \\
\text { region }\end{array}$ & 4 & 28 & 0.554 & & \\
\hline 76 & Amur region & 1 & 17 & 0.095 & \multirow[t]{4}{*}{6} & \multirow{4}{*}{$\begin{array}{l}1046 \text { mining and processing of coal and anthracite; } 1047 \text { mining and } \\
\text { processing of brown coal; } 1245 \text { production, transmission and distribution of } \\
\text { electricity; } \\
1090,1255,1270,1290,1305,1315,1400,1410 \text {. }\end{array}$} \\
\hline 65 & $\begin{array}{l}\text { Trans-Baikal } \\
\text { region }\end{array}$ & 1 & 19 & 0.113 & & \\
\hline 63 & $\begin{array}{l}\text { Republic of } \\
\text { Khakassia }\end{array}$ & 1 & 22 & 0.470 & & \\
\hline 68 & $\begin{array}{l}\text { Kemerovo } \\
\text { region }\end{array}$ & 2 & 20 & 0.630 & & \\
\hline 26 & $\begin{array}{l}\text { Novgorod } \\
\text { region }\end{array}$ & 3 & 32 & 0.092 & \multirow[t]{6}{*}{7} & \multirow{6}{*}{$\begin{array}{l}1090 \text { food production; } \\
1020,1315 \\
1025,1100,1250,1261,1263,1280,1285,1290 .\end{array}$} \\
\hline 24 & $\begin{array}{l}\text { Leningrad } \\
\text { region }\end{array}$ & 1 & 14 & 0.214 & & \\
\hline 5 & $\begin{array}{l}\text { Ivanovo } \\
\text { region }\end{array}$ & 1 & 28 & 0.437 & & \\
\hline 31 & $\begin{array}{l}\text { Krasnodar } \\
\text { region }\end{array}$ & 4 & 27 & -0.165 & & \\
\hline 64 & Altai region & 4 & 33 & 0.523 & & \\
\hline 27 & Pskov region & 4 & 35 & 0.423 & & \\
\hline 37 & $\begin{array}{l}\text { Kabardino- } \\
\text { Balkaria } \\
\text { republic }\end{array}$ & 1 & 17 & 0.452 & \multirow[t]{3}{*}{8} & \multirow{3}{*}{$\begin{array}{l}1345 \text { postal and courier activities; } \\
1261,1400,1410,1420 \\
1250,1430,1440\end{array}$} \\
\hline 62 & $\begin{array}{l}\text { Republic of } \\
\text { Tyva }\end{array}$ & 5 & 17 & 0.130 & & \\
\hline 35 & $\begin{array}{l}\text { Republic of } \\
\text { Dagestan }\end{array}$ & 5 & 19 & 0.286 & & \\
\hline
\end{tabular}


1030 fishing, fish farming; 1081 mining (except coal, oil, gas, iron ore and non-ferrous metal ores); 1305, 1315, 1340;

$1255,1261,1400,1410,1420$

\begin{tabular}{|c|c|c|c|c|c|c|}
\hline 75 & $\begin{array}{l}\text { Khabarovsk } \\
\text { region }\end{array}$ & 1 & 21 & -0.341 & & $1255,1261,1400,1410,1420$ \\
\hline 19 & $\begin{array}{l}\text { Republic of } \\
\text { Karelia }\end{array}$ & 1 & 26 & 0.377 & & \\
\hline 21 & $\begin{array}{l}\text { Arkhangelsk } \\
\text { region }\end{array}$ & 2 & 20 & 0.043 & & \\
\hline 79 & $\begin{array}{l}\text { Jewish } \\
\text { Autonomous } \\
\text { region }\end{array}$ & 5 & 21 & 0.570 & & \\
\hline 28 & St. Petersburg & 1 & 23 & -1.497 & \multirow[t]{5}{*}{10} & \multirow{5}{*}{$\begin{array}{l}1120 \text { manufacture of textiles, clothing; } 1140 \text { printing and copying of } \\
\text { information media; } \\
1110,1203,1220,1430 \text {; }\end{array}$} \\
\hline 10 & $\begin{array}{l}\text { Moscow } \\
\text { region }\end{array}$ & 1 & 39 & 0.037 & & \\
\hline 69 & $\begin{array}{l}\text { Novosibirsk } \\
\text { region }\end{array}$ & 1 & 39 & 0.358 & & \\
\hline 15 & Tver region & 1 & 42 & 0.238 & & \\
\hline 49 & Kirov region & 1 & 35 & 0.638 & & \\
\hline 74 & $\begin{array}{l}\text { Primorsky } \\
\text { region }\end{array}$ & 1 & 26 & -0.094 & \multirow[t]{5}{*}{11} & \multirow{5}{*}{$\begin{array}{l}1215 \text { production of motor vehicles and trailers; } \\
1025 \text {; } \\
1090,1095,1130,1261,1290 \text {. }\end{array}$} \\
\hline 23 & $\begin{array}{l}\text { Kaliningrad } \\
\text { region }\end{array}$ & 1 & 15 & -0.221 & & \\
\hline 46 & $\begin{array}{l}\text { Udmurt } \\
\text { Republic }\end{array}$ & 2 & 15 & -0.197 & & \\
\hline 56 & $\begin{array}{l}\text { Kurgan } \\
\text { region }\end{array}$ & 4 & 26 & 0.542 & & \\
\hline 61 & $\begin{array}{l}\text { The Republic } \\
\text { of Buryatia }\end{array}$ & 4 & 25 & 0.215 & & \\
\hline 48 & Permsky Krai & 1 & 20 & 0.340 & \multirow[t]{6}{*}{12} & \multirow[t]{6}{*}{$\begin{array}{l}1055 \text { production of crude oil and natural gas; } 1084 \text { oil and natural gas } \\
\text { production services. }\end{array}$} \\
\hline 32 & $\begin{array}{l}\text { Astrakhan } \\
\text { region }\end{array}$ & 1 & 9 & -2.436 & & \\
\hline 51 & $\begin{array}{l}\text { Orenburg } \\
\text { region }\end{array}$ & 2 & 6 & -3.332 & & \\
\hline 67 & Irkutsk region & 1 & 15 & -0.053 & & \\
\hline 66 & $\begin{array}{l}\text { Krasnoyarsk } \\
\text { region }\end{array}$ & 1 & 15 & -0.469 & & \\
\hline 53 & $\begin{array}{l}\text { Samara } \\
\text { region }\end{array}$ & 1 & 15 & -0.010 & & \\
\hline
\end{tabular}




\begin{tabular}{|c|c|c|c|c|c|c|}
\hline 20 & $\begin{array}{l}\text { Komi } \\
\text { Republic }\end{array}$ & 2 & 14 & -0.749 & & \\
\hline 58 & $\begin{array}{l}\text { Tyumen } \\
\text { region }\end{array}$ & 2 & 8 & -2.719 & & \\
\hline 71 & Tomsk region & 2 & 10 & -1.384 & & \\
\hline 72 & $\begin{array}{l}\text { Republic of } \\
\text { Sakha } \\
\text { (Yakutia) }\end{array}$ & 2 & 11 & -1.234 & & \\
\hline 45 & $\begin{array}{l}\text { Republic of } \\
\text { Tatarstan }\end{array}$ & 2 & 13 & -0.524 & & \\
\hline 18 & Moscow & 1 & 24 & -4.510 & \multirow[t]{6}{*}{13} & \multirow{6}{*}{$\begin{array}{l}1398 \text { administrative activities and related services; } 1330 \text { activities of air and } \\
\text { space transport; } 1270 \text { construction; } \\
1340 \text {; } \\
1284,1400 \text {. }\end{array}$} \\
\hline 73 & $\begin{array}{l}\text { Kamchatka } \\
\text { region }\end{array}$ & 1 & 23 & -0.231 & & \\
\hline 77 & $\begin{array}{l}\text { Magadan } \\
\text { region }\end{array}$ & 1 & 23 & -0.565 & & \\
\hline 80 & $\begin{array}{l}\text { Chukotka } \\
\text { Autonomous } \\
\text { Okrug }\end{array}$ & 2 & 13 & -0.620 & & \\
\hline 78 & $\begin{array}{l}\text { Sakhalin } \\
\text { region }\end{array}$ & 2 & 18 & -3.403 & & \\
\hline 60 & $\begin{array}{l}\text { Altai } \\
\text { Republic }\end{array}$ & 5 & 30 & -0.663 & & \\
\hline
\end{tabular}

\section{CONCLUSION}

The results of grouping regions according to the structure of strong sectors do not contradict the previously obtained results of clustering regions according to the sectoral structure of GRP. Moreover, the "processing" regions are included in the groups with the highest estimates of economic complexity. The economic complexity of the structure of the "processing" regions strong sectors is higher than that of the "agricultural" ones. The economic complexity of the strong sector's structure of "agricultural" regions is higher than that of "developing" ones. The economic complexity of the structure of strong sectors of the "developing" regions is higher than the economic complexity of the structure of the strong sectors of the "mining" regions.

The grouping of regions according to the structure of strong sectors makes it possible to clarify the characteristics of the economies of regions previously included in the "uniformly developed" cluster. The structures of strong sectors characterizing the groups of regions presented in the work can be considered as basic when choosing priority areas and forecasting the development of the regional economy.

\section{REFERENCES}

[1] Aivazian S. A., Afanasyev M. Yu., Kudrov A. A. (2016). Models of production potential and evaluation technological efficiency for the Russian Federation regions with account of production structure. Economics and Mathematical Methods, 52 (1), 28-44 (in Russian).

[2] Aivazian S. A., Afanasyev M. Yu., Kudrov A. A. (2019). Integral indicator for quality of life conditions // Digital-Economy, 1(5). 43-56. (in Russian).

[3] Balassa B. (1965). Lafayrade Liberalization and "Revealed" Comparative Advantage // The Manchester School. Vol. 33. P. 99-123.

[4] Coelho R., Hutzler S., Repetowicz P., Richmond,P.(2007): Sector analysis for a FTSE portfolio of stocks. Physica A 373, 615-626.

[5] Hartmann D. (2017) Linking Economic Complexity, Institutions, and Income Inequality //World Development Vol. 93, pp. 75-93.

[6] Hausmann R., Hidalgo C., Bustos S., Coscia M., Simoes A., Yildirim M.A. (2011). The Atlas of Economic Complexity: Mapping Pathsto Prosperity. 
Cambridge: Center for International Development, Harvard University, MIT.

[7] Hausmann R., Hwang J., \& Rodrik D. (2006). What you export matters. Journal of Economic Growth, 12(1), 1-25.

[8] Hausmann R., \& Rodrik D. (2003). Economic development as selfdiscovery. Journal of Development Economics, 72(2), 603-633

[9] Hidalgo C. A., \& Hausmann R. (2009). The building blocks of economic complexity. Proceedings of the National Academy of Sciences, 106(26), 1057010575.

[10] Hausmann R., Klinger B. (2006). Structural Transformation and Patterns of Comparative Advantage in the Product Space. Ricardo Hausmann and Bailey Klinger CID Working Paper No. 128.

[11] Jung W.-S., Kwon O.,Wang F.,Kaizoji T.,Moon H.-T., Stanley H. (2008): Group dynamics of the Japanese market. Physica A, 387, 537-542.

[12] Kemp-Benedict E. (2014): An interpretation and critique of the method of reflections. MPRA Paper No. 60705, https://mpra.ub.unimuenchen.de/60705/1/MPRA_paper_60705.pdf

[13] Kruskal J. B. (1956): On the Shortest Spanning Subtree of a Graph and the Traveling Salesman Problem. Proceedings of the American Mathematical Society, 7(1).

[14] Lee U., Kim S., Jung K.Y. (2006): Classification of epilepsy types through global network analysis of scalp electroencephalograms. Phys. Rev. E, Stat. Nonlinear Soft Matter Phys., Issue 73, Vol. 4, 19-20.

[15] Lyubimov I.L., Gvozdeva M.A., Kazakova M.V., K.V. Nesterova (2017). Economic Complexity of Russian Regions and their Potential to Diversify// NEA Journal, № 2 (34), c. 94-122 (in Russian).

[16] Makarov V. L. (2010). Social'nyj klasterizm. Rossijskij vyzov. M.: Biznes Atlas (in Russian).

[17] Onnela J.-P.(2006): Complex Networks in the Study of Financial and Social Systems. Helsinki: Helsinki University of Technology.

[18] Onnela J.-P., Chakraborti A., Kaski K., Kertesz J.(2002): Dynamic asset trees and portfolio analysis. Eur.Phys.J.,B 30, 285.
[19] Stam C.J., Tewarie P., Van Dellen E., van Straaten E.C., Hillebrand A., Van Mieqhem P. (2014): The trees and the forest: characterization of complex brain networks with minimum spanning trees. Int. J. Psychophysiol., 92, 129-138.

[20] E.M. Clarke, EA Emerson, Design and synthesis of synchronization skeletons using branching time temporal logic, in: D. Kozen (Eds.), Workshop on Logics of Programs, Lecture Notes in Computer Science, vol. 131, Springer, Berlin, Heidelberg, 1981, pp. 52-71. DOI: https://doi.org/10.1007/BFb0025774 